Received 28.04.2017 Reviewed 24.08.2017 Accepted 07.09.2017

A - study design

B - data collection

C - statistical analysis

D - data interpretation

E - manuscript preparation

F - literature search

\section{Model of water economic value optimization based on the land use change}

\footnotetext{
${ }^{1)}$ University of Brawijaya, Faculty of Engineering, Doctoral Program on Department of Water Resources, Malang, East Java Province, Indonesia; e-mail: bsgarema@yahoo.com

${ }^{2)}$ University of Brawijaya, Faculty of Engineering, Department of Water Resources, J1. Mt Haryono No 167, 65141 Malang, East Java Province, Indonesia; e-mail: lilymont2001@gmail.com,mbisri@ub.ac.id, uandawayanti@yahoo.co.id
}

For citation: Satyagraha B., Limantara L.M., Bisri M., Andawayanti U. 2018. Model of water economic value optimization based on the land use change. Journal of Water and Land Development. No. 36 p. 143-152. DOI: 10.2478/jwld-2018-0014.

\begin{abstract}
Land use change in the upstream of Rawa Pening watershed which is more and more dominated by residence and industry causes the increasing of surface flow discharge on the rainy season. In addition, the decreasing of Rawa Pening ability in storing flood discharge also influences to the cropping area in surrounded Rawa Pening. Water surpluses occurring downstream are related to the land use change in the upstream which gives impact in the downstream. However, it is as an important reason to carry out the optimization of water economic value in this region. The disruption of water availability causes the decreasing of any production like hydroelectrical power, fresh water, and rice production, so the optimal water economy is decreasing. This research intends to: 1) analyse the effect of land use change to the water availability; 2) analyse the land use change to the water balance; and 3) build and analyse the optimization model of water economic value due to the land use change. Results show that there is the different influence of land use change during the years to the results of water value optimization.
\end{abstract}

Key words: discharge, land use, model, optimization

\section{INTRODUCTION}

Conservation and demand management are the keys to sustained use of any resources. By the rapid increasing of population, secure future water for much of the world remains elusive. Planning and management of water resources is not an easy job mainly when the problem is as a national wide. It becomes harder if an area is considered unstable or when events are unpredictably [INWRDAM 2001]. The main objective of water resources planning and management is to solve the equation of demand and supply of water resource for a specific area taking into account various dimensions like time, space, politics, economy, environment, and the other aspects RISPININGTATI 2010]. Regional decision making is considered to a variety of technical aspects which need to be decided. It is an interplayed of the factual base of information about the system, the methods to process this information and the interpretation of the results.

Indonesia is as the agricultural country, so that the important aspect of water resources developments used for irrigation. Some rivers in Indonesia are progressive developed latterly. The limitation of surface water resources, especially in the dry season intensify the need for an optimum capacity and operation for the multi purposes reservoir systems [GAKPO et al. 2006; SATTARI et al. 2006]. Thus, it is needed to allo- 
cate the water use as efficient as possible. To reach this target, it is needed to make a system model for optimization. Optimization analysis would give more information for allocating water of each objective function.

The development of residential area will certainly be followed by the increasing of population growth. Every population certainly need water for their life. Therefore, water demand will be increasing from year to year. The increasing of water need will change the equilibrium of carrying capacity in the region to supply domestic water for supporting population life. Water availability tends to drop because the decreasing of carrying capacity in a watershed due to the increasing of residence area in water catchment.

Water resources development is targeted to supply water needs. The water demand is for irrigation, hydroelectrical power, industry, recreation, and human needs [LIMANTARA 2010]. The important aspect of water resources is for hydroelectrical power which gives more profit. System of water resources is as a size and activity structural and non-structural device of a development aim or improvement on available water resources for the usage of human demand [PAVONI et al. 2001]. Water management can be meant as the reconciliation of the whole users, water conservation, and the related natural resources, and the previous enough water for developing constant demand [ANDAWAYANTI et al. 2012; INWRDAM 2001].

The challenge is how to design and manage the water resources reservoir needs for a long time. The additional water demand from some users, introduction of environmental water condition, and range of the other value is as the additional challenges [JUWONO 2011; WARD 2009]. Water manager is more increasing the consultant, society, and user for merging among the users. Water catchment gets the additional pressure in number and quality of groundwater and surface water [STRATON et al. 2011].

The relation between land use changes and the decreasing of water retention capacity of the area is as a question which has to be answered by the stakeholders. In Rawa Pening watershed, the land use change in downstream is dominated by the residential and industrial area. However, it causes the increasing of surface run-off on the rainy season. In addition, the ability of Rawa Pening in storing flood discharge is also influenced by the cropping area. The surplus water which is occurring on rainy season in Rawa Pening and water deficit on dry season is related to the land use change in the upstream, and it gives so many impacts in the downstream. Therefore, it is as an important reason to carry out the optimization of water economic value in this area.

\section{MATERIALS AND METHODS}

\section{STUDY LOCATION}

Rawa Pening watershed is located in Center Java Province. The area is expanded from Rawa Pening to the regions of Kedungjati, Gubug, Dempet, Guntur, Bonang, and the estuary is in the Java Sea. Area of Rawa Pening watershed is $796 \mathrm{~km}^{2}$, it is including the catchment area in the upstream with the area of $282 \mathrm{~km}^{2}$.

Rawa Pening watershed is abut with highlands area of Merbabu, Telomoyo, and Ungaran in the southern; in the eastern is abut with Grobogan Regency and Telawa District (Demak Regency); and in the western is abut with Semarang Regency. Administratively, Rawa Pening watershed includes Semarang Regency, Salatiga City, Grobogan Regency, and Demak Regency. Map of study location is presented as in Figure 1.

The method which is used in this study is experimental method by optimization. The experiment is by reversing the component condition of watershed. However, because it concerns the wide area and long time, so the experiment is carried out indirectly such as by the simulation. To be able to carry out the simulation to the area as a system, it is needed the model that can represent the system condition. However, to obtain the model which can represent the system condition such as watershed system, it can be carried out by evaluating and studying the data of performance and the watershed that is modelled. The steps of this study are as follow:

1) to analyse the hydrological system of the watershed (process of the input-output);

2) to analyse the land use change in the watershed (the process change);

3) to analyse the water demand and availability, and the water balance change from year to year (from 1995 until 2009);

4) to analyse the water value from time to time by the approach of willingness to pay (WTP) and willingness to accept (WTA);

5) to analyse the optimization algorithm of the water benefit for period 1, 2, and 3; the period 1, 2, and 3 are following the period time of cropping season 1,2 , and 3 ;

6) modelling of the optimization.

\section{OPTIMIZATION BY LINEAR PROGRAMMING}

Optimization is a design in the plan models solving based on the mathematical function that limits it. There are some optimization techniques with the constraints as follow [LIMANTARA, SOETOPO 2011]:

1) Langrange multipliers is as an optimization solving by using the linear constraints;

2) linear programming is as an optimization solving by using the linear constraints;

3) quadratic programming is as an optimization solving by using the mathematic program with the linear function and non linear objective function;

4) geometric programming is as an optimization solving by using the geometric equation;

5) dynamic programming is as an approach to optimize the decision processes in double steps. 


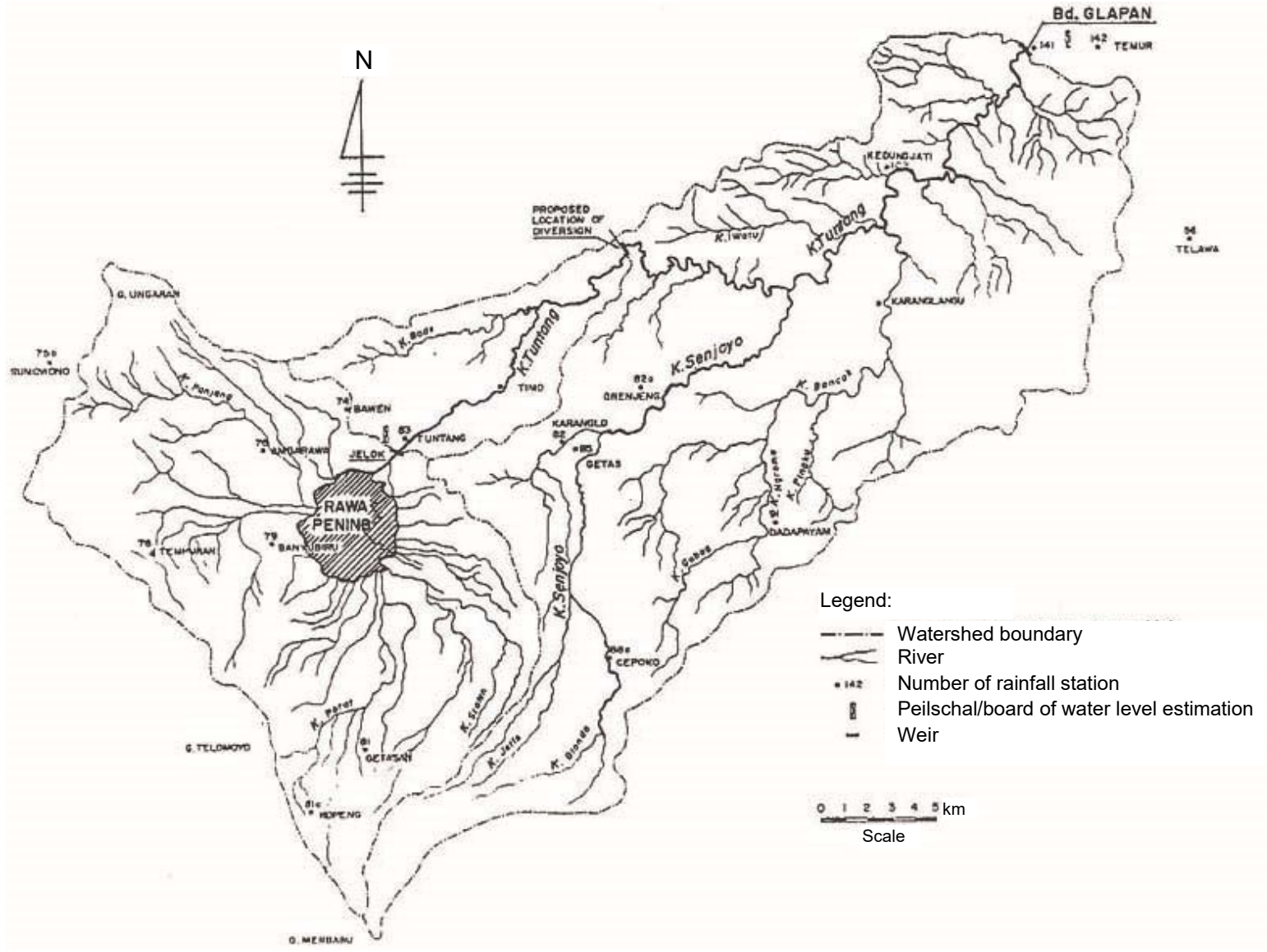

Fig. 1. Location of Rawa Pening watershed; source: BPPT [2013]

Analysis in this study uses linear programming. The selection of this method is based on the considerations as follow [LIMANTARA, SOETOPO 2011]:

1) this method can be used for solving the system with pretty much variables and constraints;

2) the usage of this method is easy. in addition, it is supported by much program packages which has been published;

3) the mathematical function is simple;

4) the result is reliable enough.

The steps in carrying out analysis with the linear programming are as follow:

1) to make the optimization model;

2) to determine the sources which will be optimized (in this case is used for irrigation, hydroelectrical power, and drinking water);

3 ) to analyse the quantity of input and output for every activity unit;

4) setting of the mathematical model.

\section{MODEL OF LINEAR PROGRAMMING}

Basically, model of linear programming has three important factors as follow:

1) decision variable is as the variable which will be found and giving the best value for the objective that will be reached;

2) objective function is as the mathematical function which has been maximized or minimized and it reflects the objective which will be reached;
3) constraint is as the mathematical function which becomes as the constraint of the effort to maximize or minimize of the objective function that represents the constraint that has to be reached.

There are four basic assumptions implicity built into linear programming model as follow [MAYS, TUNG 1992]:

- proportionally assumption - this implies that the contribution of the $j^{\text {th }}$ decision variable to the effectiveness measure, $c_{j} x_{j}$ and its usage of the various resources, $a_{i j} x_{i}$, are directly proportional to the value of the decision variable;

- additivity assumption - the assumption means that, at a given level of activity $\left(x_{1}, x_{2}, x_{n}\right)$, the total usage of resources and contribution to the overall measure of effectiveness are equal to the sum of the corresponding quantities generated by each activity conducted by itself;

- divisibility assumption - activity units can be divided into any fractional level, so not integer values for the decision variables are permissible;

- determistic assumption - all parameters in the model are known constants without uncertainty. The effect of the uncertainty of parameters on the result can be investigated by conducting sensitivity analysis.

A general mathematical form of an optimization problem is as follow [LIMANTARA, SOETOPO 2011; SIMONOVIC 2009]: 
Objective function:

$$
Z=c_{1} x_{1}+c_{2} x_{2}+c_{3} x_{3}+\ldots .+c_{n} x_{n}
$$

Constraint:

$$
\begin{gathered}
a_{11} x_{1}+a_{12} x_{2}+\ldots+a_{1 n} \leq b_{1} \\
a_{12} x_{1}+a_{22} x_{2}+\ldots+a_{2 n} x_{n} \leq b_{2} \\
m a_{m 1} x_{1}+a_{m 2} x_{2}+\ldots+a_{m n} x_{n} \leq b_{m} \\
x_{1} \geq 0 ; x_{2} \geq 0 ; \ldots ; x_{n} \geq 0
\end{gathered}
$$

Where: $Z=$ objective function; $C_{1}, \ldots, C_{n}=$ objective function coefficient; $a_{11} \ldots, a_{m n}=$ coefficient of constraint variable; $x_{1} \ldots, x_{n}=$ constraint variable; $m=$ total constraint; $n=$ total number of decision variable.

The objective is usually to find the best possible water allocation (for water supply, hydropower generation, irrigation etc.) within a given time period in the complex water system. For most practical water management applications, the nonlinearity of the objective function and/or constraints mean that many modifications have been used to convert the non-linear problems for the use of linear programming solver [SIMONOVIC 2009].

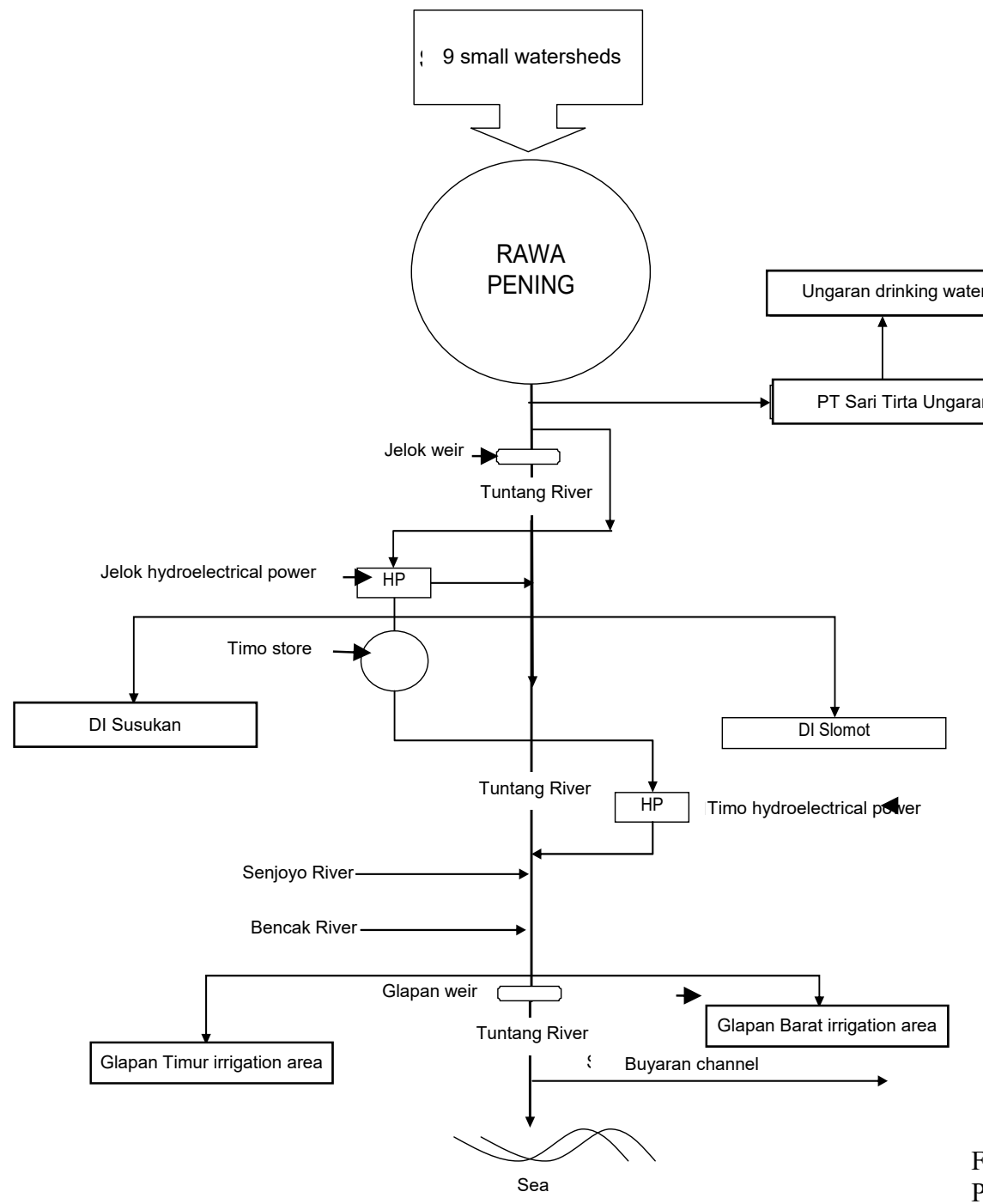

Fig. 2. System of upstream Rawa Pening watershed; own elaboration 
- inflow to the Rawa Pening reservoir (I) which is analysed based on the outflow data that is recorded in the hydroelectrical power of Jelok;

- evapotranspiration (ETo) which is obtained from data of the nearest pan-evaporation multiplied by cropping coefficient.

2. Dependent variables consist of:

- energy of the Jelok hydroelectrical power $(E j)$; there are 4 turbines which can be generated by water potential energy of the Rawa Pening reservoir that is flowed to the intake in the Jelok weir of Tuntang River; the Jelok hydroelectrical power has installed capacity of $5.12 \mathrm{Wh}$.

- energy of the Timo hydroelectrical power $(E t)$ after being used by the Jelok hydroelectrical power; the Timo hydroelectrical power has 3 turbines and the installed capacity is $4.17 \mathrm{Wh}$;

- water volume of reservoir $(R)$ is as outflow of the Jelok weir which is through the intake of hydroelectrical power as well as irrigation gate and as the overflow into the Tuntang River;

- initial storage volume of the Rawa Pening reservoir $\left(S_{i}\right)$ is as the water volume total of the Rawa Pening reservoir when $t=0$;

- water discharge which is used by the PT Sari Tirta Ungaran $\left(Q_{1}\right)$ for drinking water. Intake is in the upstream Jelok weir and the average discharge is $50 \mathrm{dm}^{3} \mathrm{~s}^{-1}$;

- water discharge which is used by the Jelok hydroelectrical power $\left(Q_{2}\right)$. It is based on the water level elevation of the Rawa Pening watershed;

- water discharge for irrigation in the irrigation area of Slomot $\left(Q_{3}\right)$ and Susukan $\left(Q_{4}\right)$, based on the cropping pattern which has been determined by regional irrigation committee there;

- water discharge for irrigation in the irrigation area of Kenteng and Tapen $\left(Q_{6}\right)$; the intake is in the downstream intake of the Slomot irrigation area; it is based on the cropping pattern which has been determined by the regional irrigation committee there.

To make more convincing the variables which are influencing the water value in the Rawa Pening, is carried out by using the structural equation modeling (SEM) with partial least square (PLS) of SmartPLS program. The results of PLS are as follow:

1) there is the significant positive influence of land use to the water quality; it means that the higher indicator value of the land use can increase the indicator value of the water quality such as TSS and BOD;

2) there is the significant positive influence of the land use to the water quantity; it means that the higher indicator value of the land use can increase the indicator of water quantity;

3) there is the significant positive influence of the water quality to the water economic value; it means that the better water quality can increase the water economic value;

4) there is the non-significant positive influence of the water quantity to the water economic value; it means that the higher indicator value of the water quantity can increase the water economic value but it is non-significant;

5) there is the significant positive influence of the land use to the water economic value; it means that the higher indicator value of the land use can increase the water economic value.

There are used 18 variables for the optimization in the Rawa Pening system as follow:

$x_{1}=$ volume of the drinking water period 1 in Sari Tirta Ungaran (STU), $\mathrm{m}^{3}$;

$x_{2}=$ volume of the drinking water period 2 in Sari Tirta Ungaran (STU), $\mathrm{m}^{3}$;

$x_{3}=$ volume of the drinking water period 3 in Sari Tirta Ungaran (STU), $\mathrm{m}^{3}$;

$x_{4}=$ energy period 1 of the Jelok hydroelectrical power, kWh;

$x_{5}=$ energy period 2 of the Jelok hydroelectrical power, kWh;

$x_{6}=$ energy period 3 of the Jelok hydroelectrical power, kWh;

$x_{7}=$ energy period 1 of the Timo hydroelectrical power, kWh;

$x_{8}=$ energy period 2 of the Timo hydroelectrical power, kWh;

$x_{9}=$ energy period 3 of the Timo hydroelectrical power, kWh;

$x_{10}=$ number area period 1 of the Kenteng irrigation area (paddy-cropping pattern-1), ha;

$x_{11}=$ number area period 2 of the Kenteng irrigation area (paddy-cropping pattern-2), ha;

$x_{12}=$ number area period 2 of the Kenteng irrigation area (second crop-cropping pattern-3), ha;

$x_{13}=$ number area period 1 of the Tapen irrigation area (paddy-cropping pattern-1), ha;

$x_{14}=$ number area period 1 of the Tapen irrigation area (paddy-cropping pattern-2), ha;

$x_{15}=$ number area period 2 of the Tapen irrigation area (second crop-cropping pattern-3), ha;

$x_{16}=$ number area period 1 of the Slomot irrigation area (paddy-cropping pattern-1), ha;

$x_{17}=$ number area period 1 of the Slomot irrigation area (paddy-cropping pattern-2), ha;

$x_{18}=$ number area period 2 of the Slomot irrigation area (second crop-cropping pattern-3), ha.

Objective function:

$\operatorname{Max} x_{1} \cdot\left(\mathrm{Rp} \cdot \mathrm{m}^{-3}\right)+x_{2} \cdot\left(\mathrm{Rp} \cdot \mathrm{m}^{-3}\right)+x_{3} \cdot\left(\mathrm{Rp} \cdot \mathrm{m}^{-3}\right)+$ $x_{4} \cdot\left(\mathrm{Rp} \cdot \mathrm{kWh}^{-1}\right)+x_{5} \cdot\left(\mathrm{Rp} \cdot \mathrm{kWh}^{-1}\right)+x_{6} \cdot\left(\mathrm{Rp} \cdot \mathrm{kWh}^{-1}\right)+$

$x_{7} \cdot\left(\mathrm{Rp} \cdot \mathrm{kWh}^{-1}\right)+x_{8} \cdot\left(\mathrm{Rp} \cdot \mathrm{kWh}^{-1}\right)+x_{9} \cdot\left(\mathrm{Rp} \cdot \mathrm{kWh}^{-1}\right)+$

$x_{10} \cdot\left(\mathrm{Rp} \cdot \mathrm{ha}^{-1}\right)+x_{11} \cdot\left(\mathrm{Rp} \cdot \mathrm{ha}^{-1}\right)+x_{12} \cdot\left(\mathrm{Rp} \cdot \mathrm{ha}^{-1}\right)+$

$x_{13} \cdot\left(\mathrm{Rp} \cdot \mathrm{ha}^{-1}\right)+x_{14} \cdot\left(\mathrm{Rp} \cdot \mathrm{ha}^{-1}\right)+x_{15} \cdot\left(\mathrm{Rp} \cdot \mathrm{ha}^{-1}\right)+$

$x_{16} \cdot\left(\mathrm{Rp} \cdot \mathrm{ha}^{-1}\right)+x_{17} \cdot\left(\mathrm{Rp} \cdot \mathrm{ha}^{-1}\right)+x_{18} \cdot\left(\mathrm{Rp} \cdot \mathrm{ha}^{-1}\right)+$

$\mathrm{KW}_{\text {PLTA JELOK }} \cdot\left(\mathrm{Rp} \cdot \mathrm{KW}^{-1}\right)+\mathrm{KW}_{\text {PLTA TIMO }} \cdot\left(\mathrm{Rp} \cdot \mathrm{KW}^{-1}\right)$

\section{CONSTRAINT}

Drinking water (Sarana Tirta Ungaran - STU)

$50 \mathrm{dm}^{3} \cdot \mathrm{s}^{-1} \leq x_{1} \leq 250 \mathrm{dm}^{3} \cdot \mathrm{s}^{-1}$

$50 \mathrm{dm}^{3} \cdot \mathrm{s}^{-1} \leq x_{2} \leq 250 \mathrm{dm}^{3} \cdot \mathrm{s}^{-1}$

$50 \mathrm{dm}^{3} \cdot \mathrm{s}^{-1} \leq x_{3} \leq 250 \mathrm{dm}^{3} \cdot \mathrm{s}^{-1}$ 


\section{Hydroelectrical power of Jelok}

$x_{4} \leq$ maximum generation discharge on the period 1 ;

$x_{5} \leq$ maximum generation discharge on the period 2 ;

$x_{6} \leq$ maximum generation discharge on the period 3 .

Hydroelectrical power of Timo

$x_{7} \leq$ maximum generation discharge on the period 1 ;

$x_{8} \leq$ maximum generation discharge on the period 2 ;

$x_{9} \leq$ maximum generation discharge on the period 3 .

Irrigation area of Kenteng

$x_{10} \geq 75 \%$ of available irrigation area on the period 1

(MT 1);

$x_{11} \geq 75 \%$ of available irrigation area on the period 2

(MT 2);

$x_{12} \geq 75 \%$ of available irrigation area on the period 3

(MT 3).

Irrigation area of Tapen

$x_{13} \geq 75 \%$ of available irrigation area on the period 1

(MT 1);

$x_{14} \geq 75 \%$ of available irrigation area on the period 2

(MT 2);

$x_{15} \geq 75 \%$ of available irrigation area on the period 3 (MT 3).

Irrigation area of Slomot

$x_{16} \geq 75 \%$ of available irrigation area on the period 1 (MT 1);

$x_{17} \geq 75 \%$ of available irrigation area on the period 2

(MT 2);

$x_{18} \geq 75 \%$ of available irrigation area on the period 3

(MT 3).

Discharge on the cropping season $1(\operatorname{period} 1$, MT 1$)$

$x_{1}+x_{4}+x_{7}+x_{10}+x_{13}+x_{16} \leq Q_{\mathrm{I}}$

Discharge on the cropping season 2 (period 2, MT 2)

$x_{2}+x_{5}+x_{8}+x_{11}+x_{14}+x_{17} \leq Q_{\mathrm{II}}$

Discharge on the cropping season $3(\operatorname{period} 3$, MT 3$)$

$x_{3}+x_{6}+x_{9}+x_{12}+x_{15}+x_{18} \leq Q_{\text {III }}$

Water quality

Oxygen $/ x_{1} \leq \mathrm{BOD}_{1}($ period 1, MT 1$)$

Oxygen $/ x_{2} \leq \mathrm{BOD}_{2}($ period 2 , MT 2)

Oxygen $/ x_{3} \leq \mathrm{BOD}_{3}($ period 3, MT 3$)$

ANALYSIS AND RESULT ANALYSIS OF OPTIMIZATION ANALYSIS BASED ON THE DATA 1995-2009 DUE TO THE THREE DISCHARGE CONDITION OF DRY DISCHARGE (66.6\%), NORMAL DISCHARGE (50\%), AND WET DISCHARGE (33.3\%)

Optimization is carried out on the Rawa Pening system which includes 2 hydroelectrical powers such as Jelok and Timo; 3 irrigation area such as Kenteng, Tapen, and Slomot; drinking water in Sarana Tirta Ungaran (STU); and by attending the water quality. Based on the description as above, there are needed 18 variables and 27 constraints for the optimization analysis. For example, there is given the objective function and constraints for the wet discharge condition $(33.3 \%)$ as follow:

- Objective function (to maximize)

$x_{1} \cdot 7,500+x_{2} \cdot 7,500+x_{3} \cdot 7,500+x_{4} \cdot 33,039,715,416+$

$x_{5} \cdot 40,142,518,775+x_{6} \cdot 20,705,176,289+$

$x_{7} \cdot 19,232,798,674+x_{8} \cdot 19,232,798,674+$ $x_{9} \cdot 19,232,798,674+x_{10} \cdot 472,950,000+$

$x_{11} \cdot 472,950,000+x_{12} \cdot 104,962,500+x_{13} \cdot 620,090,000$

$+x_{14} \cdot 620,090,000+x_{15} \cdot 137,617,500+$

$x_{16} \cdot 2,837,700,000+x_{17} \cdot 2,837,700,000+$

$x_{18} \cdot 629,775,000+15,000 \cdot 994.8+10,500 \cdot 994.8$

In Rp (Indonesian currency).

- Constraints

Drinking water (Sarana Tirta Ungaran - STU)

$x_{1} \leq 0.25 \mathrm{~m}^{3} \cdot \mathrm{s}^{-1}$

$x_{2} \leq 0.25 \mathrm{~m}^{3} \cdot \mathrm{s}^{-1}$

$x_{3} \leq 0.25 \mathrm{~m}^{3} \cdot \mathrm{s}^{-1}$

$x_{1} \geq 0.05 \mathrm{~m}^{3} \cdot \mathrm{s}^{-1}$

$x_{2} \geq 0.05 \mathrm{~m}^{3} \cdot \mathrm{s}^{-1}$

$x_{3} \geq 0.05 \mathrm{~m}^{3} \cdot \mathrm{s}^{-1}$

Hydroelectrical power of Jelok

$x_{4} \leq 13.6 \mathrm{kWh}$

$x_{5} \leq 13.6 \mathrm{kWh}$

$x_{6} \leq 8.0 \mathrm{kWh}$

Hydroelectrical power of Timo

$x_{7} \leq 13.6 \mathrm{kWh}$

$x_{8} \leq 13.6 \mathrm{kWh}$

$x_{9} \leq 8.0 \mathrm{kWh}$

Irrigation area of Kenteng

$x_{10} \geq 0.039$ ha

$x_{11} \geq 0.039$ ha

$x_{12} \geq 0.0098$ ha

Irrigation area of Tapen

$x_{13} \geq 0.051$ ha

$x_{14} \geq 0.051$ ha

$x_{15} \geq 0.013$ ha

Irrigation area of Slomot

$x_{16} \geq 0.23$ ha

$x_{17} \geq 0.23$ ha

$x_{18} \geq 0.059$ ha

Discharge on the cropping season $1($ period 1, MT 1$)$ $x_{1}+x_{4}+x_{7}+x_{10}+x_{13}+x_{16} \leq 12.09 \mathrm{~m}^{3}$

Discharge on the cropping season 2 (period 2, MT 2) $x_{2}+x_{5}+x_{8}+x_{11}+x_{14}+x_{17} \leq 12.09 \mathrm{~m}^{3}$

Discharge on the cropping season 3 (period 3, Mt 3) $x_{3}+x_{6}+x_{9}+x_{12}+x_{15}+x_{18} \leq 12.09 \mathrm{~m}^{3}$

Water quality

$4.07 / x_{1} \leq 3($ period 1, MT 1$)$

$4.07 / x_{2} \leq 3($ period 2, MT 2$)$

$4.07 / x_{3} \leq 3($ period 3, MT 3$)$

Explanation: $4.07=$ oxygen demand in $\mathrm{m}^{3}$.

Optimization result by using the linear programming on the Rawa Pening system with the three discharge condition of dry discharge $(66.6 \%)$; normal discharge $(50 \%)$; and wet discharge $(33.3 \%)$ are presented on Table 1. Figure 3 presents the inflowoutflow condition of optimization result based on the data of 1995-2009 for the discharge condition of dry (66.6\%); normal (50\%); and wet (33.3\%).

Based on the running result of optimization by using linear programming based on the data of 19952009 , there is produced the maximum benefit for 3 periods of cropping season on the wet discharge condition is as $\mathrm{Rp} 875,362,267,553.0$; on the normal discharge condition is as $\mathrm{Rp} 850,923,126,361.0$; and on the dry discharge condition is as $\mathrm{Rp} 725,882,198,274.0$. 
Table 1. Optimization result based on the data of 1995-2009

\begin{tabular}{|c|c|c|c|c|c|c|c|c|c|c|c|}
\hline \multirow{3}{*}{ Year } & \multirow{3}{*}{ Period } & \multirow{2}{*}{\multicolumn{2}{|c|}{ Inflow }} & & & & lation of $\mathrm{o}$ & flow & & & \multirow{3}{*}{$\begin{array}{c}\text { Benefit } \\
\text { Rp }\end{array}$} \\
\hline & & & & DW & $\mathrm{HP}$ & $\mathrm{HP}$ & IA & IA & IA & total & \\
\hline & & $Q, \mathrm{~m}^{3} \cdot \mathrm{s}^{-1}$ & volume, $\mathrm{m}^{3}$ & \multicolumn{7}{|c|}{$Q, \mathrm{~m}^{3} \cdot \mathrm{s}^{-1}$} & \\
\hline \multirow{3}{*}{ Normal } & 1 & 9.03 & $23,717,837$ & 0.25 & 4.22 & 4.22 & 0.04 & 0.05 & 0.23 & 9.02 & \multirow{3}{*}{$643,387,683,803$} \\
\hline & 2 & 9.03 & $23,717,837$ & 0.25 & 4.22 & 4.22 & 0.04 & 0.05 & 0.23 & 9.02 & \\
\hline & 3 & 9.03 & $23,717,837$ & 0.25 & 4.28 & 4.28 & 0.01 & 0.01 & 0.06 & 8.88 & \\
\hline \multirow{3}{*}{ Dry } & 1 & 5.55 & $14,577,408$ & 0.25 & 2.48 & 2.48 & 0.04 & 0.05 & 0.23 & 5.54 & \multirow{3}{*}{$377,831,171,617$} \\
\hline & 2 & 5.55 & $14,577,408$ & 0.25 & 2.48 & 2.48 & 0.04 & 0.05 & 0.23 & 5.54 & \\
\hline & 3 & 5.55 & $14,577,408$ & 0.25 & 2.49 & 2.49 & 0.01 & 0.01 & 0.06 & 5.31 & \\
\hline \multirow{3}{*}{ Wet } & 1 & 12.09 & $31,755,110$ & 0.25 & 5.75 & 5.75 & 0.04 & 0.05 & 0.23 & 12.08 & \multirow{3}{*}{$875,362,267,553$} \\
\hline & 2 & 12.09 & $31,755,110$ & 0.25 & 5.75 & 5.75 & 0.04 & 0.05 & 0.23 & 12.08 & \\
\hline & 3 & 12.09 & $31,755,110$ & 0.25 & 5.93 & 5.67 & 0.01 & 0.01 & 0.06 & 11.94 & \\
\hline
\end{tabular}

Explanations: $\mathrm{DW}=$ drinking water; $\mathrm{HP}=$ hydro power; $\mathrm{IA}=$ irrigation area.

Source: own study

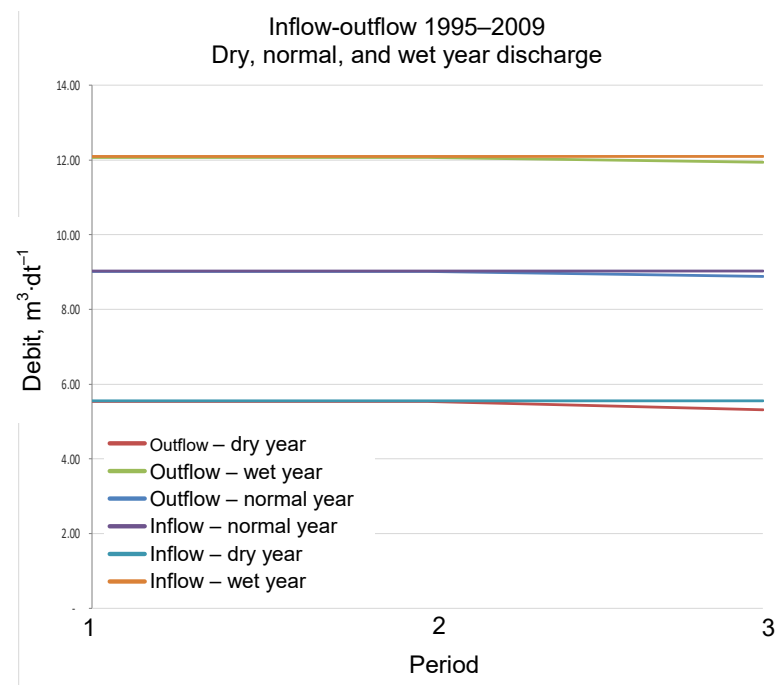

Fig. 3. Optimization result of inflow-outflow (1995-2009); source: own study
Based on the SEM analysis, the land use change indicated the significant influence to the optimization model of water economic value. Therefore, this optimization is also carried out on the year of 1995, 2003, and 2009 when there were occurring land use changes due to the mapping of land use. There is also carried out the optimization for the years of 1995, 2003, and 2009 based on the three discharge conditions such as wet discharge condition $(33.3 \%)$, normal discharge condition $(50 \%)$, and dry discharge condition $(66.6 \%)$. The results are presented for 1995, 2003 and 2009 as in the Table 2 and Figure 4.

Running of optimization model by using linear programming based on the data of 1995 indicates the maximum benefit for the three discharge conditions as follow: for the wet is as $\operatorname{Rp} 954,418,586,400.0$; for the normal is as $\mathrm{Rp} 850,923,126,361.0$; and for the dry is as $\operatorname{Rp} 725,882,198,274.0$.

Table 2. Optimization result based on the data of 1995, 2003 and 2009

\begin{tabular}{|c|c|c|c|c|c|c|c|c|c|c|c|}
\hline \multirow{3}{*}{ Year } & \multirow{3}{*}{ Period } & \multirow{2}{*}{\multicolumn{2}{|c|}{ Inflow }} & \multicolumn{7}{|c|}{ Simulation of outflow } & \multirow{3}{*}{$\begin{array}{l}\text { Benefit } \\
\text { Rp }\end{array}$} \\
\hline & & & & DW & HP Jelok & HP Timo & IA Kenteng & IA Tapen & IA Slomot & total & \\
\hline & & $Q, \mathrm{~m}^{3} \cdot \mathrm{s}^{-1}$ & volume, $\mathrm{m}^{3}$ & \multicolumn{7}{|c|}{$Q, \mathrm{~m}^{3} \cdot \mathrm{s}^{-1}$} & \\
\hline 1 & 2 & 3 & 4 & 5 & 6 & 7 & 8 & 9 & 10 & 11 & 12 \\
\hline \multicolumn{12}{|c|}{1995} \\
\hline \multirow{3}{*}{ Normal } & 1 & 11.80 & $30,993,408$ & 0.25 & 5.60 & 5.60 & 0.04 & 0.05 & 0.23 & 11.78 & \multirow{3}{*}{$850,923,126,361$} \\
\hline & 2 & 11.80 & $30,993,408$ & 0.25 & 5.60 & 5.60 & 0.04 & 0.05 & 0.23 & 11.78 & \\
\hline & 3 & 11.80 & $30,993,408$ & 0.25 & 5.00 & 5.00 & 0.01 & 0.01 & 0.06 & 10.33 & \\
\hline \multirow{3}{*}{ Dry } & 1 & 9.95 & $26,134,272$ & 0.25 & 4.67 & 4.67 & 0.04 & 0.05 & 0.23 & 9.92 & \multirow{3}{*}{$725,882,198,274$} \\
\hline & 2 & 9.95 & $26,134,272$ & 0.25 & 4.67 & 4.67 & 0.04 & 0.05 & 0.23 & 9.92 & \\
\hline & 3 & 9.95 & $26,134,272$ & 0.25 & 4.53 & 4.53 & 0.01 & 0.01 & 0.06 & 9.40 & \\
\hline \multirow{3}{*}{ Wet } & 1 & 13.09 & $34,381,670$ & 0.25 & 6.20 & 6.20 & 0.04 & 0.05 & 0.23 & 12.98 & \multirow{3}{*}{$954,418,586,400$} \\
\hline & 2 & 13.09 & $34,381,670$ & 0.25 & 6.20 & 6.20 & 0.04 & 0.05 & 0.23 & 12.98 & \\
\hline & 3 & 13.09 & $34,381,670$ & 0.25 & 5.93 & 5.67 & 0.01 & 0.01 & 0.06 & 11.94 & \\
\hline \multicolumn{12}{|c|}{2003} \\
\hline \multirow{3}{*}{ Normal } & 1 & 12.85 & $33,751,296$ & 0.25 & 6.10 & 6.10 & 0.04 & 0.05 & 0.23 & 12.78 & \multirow{3}{*}{$868,170,664,751$} \\
\hline & 2 & 12.85 & $33,751,296$ & 0.25 & 6.10 & 6.10 & 0.04 & 0.05 & 0.23 & 12.78 & \\
\hline & 3 & 12.85 & $33,751,296$ & 0.25 & 5.00 & 5.00 & 0.01 & 0.01 & 0.06 & 10.33 & \\
\hline \multirow{3}{*}{ Dry } & 1 & 6.81 & $17,886,874$ & 0.25 & 3.10 & 3.10 & 0.04 & 0.05 & 0.23 & 6.78 & \multirow{3}{*}{$455,477,684,937$} \\
\hline & 2 & 6.81 & $17,886,874$ & 0.25 & 3.10 & 3.10 & 0.04 & 0.05 & 0.23 & 6.78 & \\
\hline & 3 & 6.81 & $17,886,874$ & 0.25 & 2.95 & 2.95 & 0.01 & 0.01 & 0.06 & 6.22 & \\
\hline \multirow{3}{*}{ Wet } & 1 & 14.11 & $37,060,762$ & 0.25 & 6.75 & 6.75 & 0.04 & 0.05 & 0.23 & 14.08 & \multirow{3}{*}{$968,861,186,119$} \\
\hline & 2 & 14.11 & $37,060,762$ & 0.25 & 6.75 & 6.75 & 0.04 & 0.05 & 0.23 & 14.08 & \\
\hline & 3 & 14.11 & $37,060,762$ & 0.25 & 5.93 & 5.67 & 0.01 & 0.01 & 0.06 & 11.94 & \\
\hline
\end{tabular}


contin. Tab. 2

\begin{tabular}{|c|c|c|c|c|c|c|c|c|c|c|c|}
\hline 1 & 2 & 3 & 4 & 5 & 6 & 7 & 8 & 9 & 10 & 11 & 12 \\
\hline \multicolumn{12}{|c|}{2009} \\
\hline \multirow{3}{*}{ Normal } & 1 & 10.29 & $27,027,302$ & 0.25 & 4.85 & 4.85 & 0.04 & 0.05 & 0.23 & 10.28 & \multirow{3}{*}{$727,704,108,909$} \\
\hline & 2 & 10.29 & $27,027,302$ & 0.25 & 4.85 & 4.85 & 0.04 & 0.05 & 0.23 & 10.28 & \\
\hline & 3 & 10.29 & $27,027,302$ & 0.25 & 4.63 & 4.63 & 0.01 & 0.01 & 0.06 & 9.58 & \\
\hline \multirow{3}{*}{ Dry } & 1 & 7.95 & $20,881,152$ & 0.25 & 3.67 & 3.67 & 0.04 & 0.05 & 0.23 & 7.92 & \multirow{3}{*}{$528,863,869,756$} \\
\hline & 2 & 7.95 & $20,881,152$ & 0.25 & 3.67 & 3.67 & 0.04 & 0.05 & 0.23 & 7.92 & \\
\hline & 3 & 7.95 & $20,881,152$ & 0.25 & 2.95 & 2.95 & 0.01 & 0.01 & 0.06 & 6.22 & \\
\hline \multirow{3}{*}{ Wet } & 1 & 13.18 & $34,618,061$ & 0.25 & 6.30 & 6.30 & 0.04 & 0.05 & 0.23 & 13.18 & \multirow{3}{*}{$936,768,574,899$} \\
\hline & 2 & 13.18 & $34,618,061$ & 0.25 & 6.30 & 6.30 & 0.04 & 0.05 & 0.23 & 13.18 & \\
\hline & 3 & 13.18 & $34,618,061$ & 0.25 & 5.93 & 5.67 & 0.01 & 0.01 & 0.06 & 11.94 & \\
\hline
\end{tabular}

Explanations as below the Table 1 .

Source: own study.
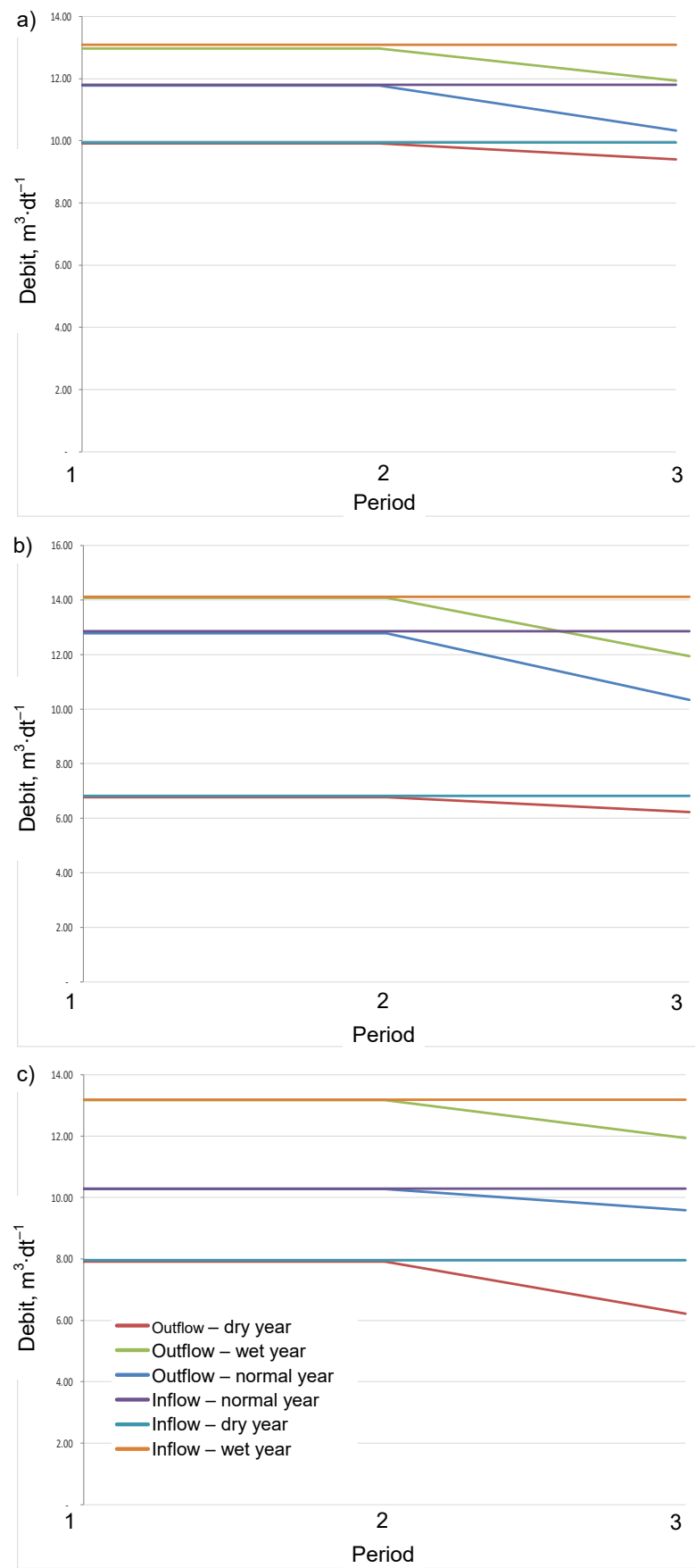

Fig. 4. Optimization result of inflow-outflow based on the data of: a) 1995, b) 2003, c) 2009; source: own study
Running of optimization model by using the linear programming based on the data of 2003 indicates the maximum benefit for the three discharge conditions are as follow: for the wet is as $\mathrm{Rp}$ $968,861,186,119.0$; for the normal is as $\mathrm{Rp}$ $868,170,664,751.0$; and for the dry is as $\mathrm{Rp}$ 455,477,684,937.0.

Running of optimization model by using linear programming based on the data of 2009 indicates the maximum benefit for the three discharge conditions as follow: for the wet is as Rp 936,768,574,899.-1 for the normal is as Rp 727,704,108,909.0; and for the dry is as $\operatorname{Rp} 528,869,869,756.0$.

Recapitulation of optimization result for 19952009 based on the mapping year of land use change of 1995, 2003, and 2009 each for the discharge condition of wet, normal, and dry are presented as in Table 3.

Recapitulation as presented in the Table 3 indicate that the benefit based on the data 1995-2009, on the year of 1995 gives the same benefit for all discharge condition such as wet $(33.3 \%)$, normal $(50 \%)$, and dry $(66.6 \%)$. This result indicates that the land use change on 1995 is not significant although the SEM analysis result gives the significant result of the land use change based on the data of 1995-2009.

There is the benefit increasing from 1995 until 2003 for the wet discharge condition (33.3\%) and normal $(50 \%)$, but for the dry discharge condition $(66.6 \%)$ there is happened the high enough decreasing of the benefit. It indicates that the land use change is very significant influencing the benefit on the dry discharge condition $(66.6 \%)$. It is due to the water availability of the land use change year on 2003 is very limited on the wet discharge condition $(66.6 \%)$, so there is the priority which is responsible to be fulfilled like drinking water.

For the land use change on 2009, there is the benefit decreasing for the wet discharge condition (33.3\%) and normal discharge condition (50\%). It is regarding to the SEM analysis result which presents that the land use change is significantly influencing the water value optimization. The land use change increasingly influences the water availability on the Rawa Pening system. Although there is the increasing benefit on the wet discharge condition (33.3\%), it is increasingly caused by the significant decreasing from 1995 until 2003. 
Table 3. Optimization result of the wet, normal and dry discharge condition on 1995-2009

\begin{tabular}{|c|c|c|c|c|}
\hline Item & 1995-2009 & 1995 & 2003 & 2009 \\
\hline \multicolumn{5}{|c|}{ Wet discharge condition $(33.3 \%)$} \\
\hline Drinking water, $\mathrm{m}^{3}$ & $1,969,920$ & $1,969,920$ & $1,969,920$ & $1,969,920$ \\
\hline Hydro power of Jelok, $\mathrm{kWh}$ & $50,345,879$ & $52,930,332$ & $56,089,108$ & $53,504,655$ \\
\hline Hydro power of Timo, $\mathrm{kWh}$ & $40,521,604$ & $42,634,292$ & $45,216,466$ & $43,103,778$ \\
\hline Irrigation area of Kenteng, \% & 244 & 244 & 244 & 244 \\
\hline Irrigation area of, $\%$ & 225 & 225 & 225 & 225 \\
\hline Irrigation area of Slomot, $\%$ & 226 & 226 & 226 & 226 \\
\hline BOD & 16 & 16 & 16 & 16 \\
\hline Benefit, Rp & $954,418,586,400.0$ & $954,418,586,400.0$ & $968,861,186,119.0$ & $936,768,574,899.0$ \\
\hline \multicolumn{5}{|c|}{ Normal discharge condition $(50 \%)$} \\
\hline Drinking water, $\mathrm{m}^{3}$ & $1,969,920$ & $1,969,920$ & $1,969,920$ & $1,969,920$ \\
\hline Hydro power of Jelok, kWh & $36,715,491$ & $46,757,480$ & $49,629,095$ & 41355,403 \\
\hline Hydro power of Timo, $\mathrm{kWh}$ & $30,013,457$ & $38,222,384$ & $40,569,815$ & $33,806,401$ \\
\hline Irrigation area of Kenteng, \% & 225 & 225 & 225 & 225 \\
\hline Irrigation area of, $\%$ & 225 & 225 & 225 & 225 \\
\hline Irrigation area of Slomot, $\%$ & 225 & 225 & 225 & 225 \\
\hline BOD & 16 & 16 & 16 & 16 \\
\hline Benefit, Rp & $850,923,126,361.0$ & $850,923,126,361.0$ & $868,170,664,751.0$ & $727,704,108,909.0$ \\
\hline \multicolumn{5}{|c|}{$\begin{array}{l}\text { Dry discharge condition }(66.6 \%) \\
\end{array}$} \\
\hline Drinking water, $\mathrm{m}^{3}$ & $1,969,920$ & $1,969,920$ & $1,969,920$ & $1,969,920$ \\
\hline Hydro power of Jelok, $\mathrm{kWh}$ & $21,511,716$ & $40,051,607$ & $26,400,699$ & $29,674,340$ \\
\hline Hydro power of Timo, $\mathrm{kWh}$ & $17,584,974$ & $32,740,600$ & $21,581,524$ & $24,257,595$ \\
\hline Irrigation area of Kenteng, $\%$ & 225 & 225 & 225 & 225 \\
\hline Irrigation area of, $\%$ & 225 & 225 & 225 & 225 \\
\hline Irrigation area of Slomot, $\%$ & 225 & 225 & 225 & 225 \\
\hline BOD & 16 & 16 & 16 & 16 \\
\hline Benefit, Rp & $725,882,198,274.0$ & $725,882,198,274.0$ & $455,477,684,937.0$ & $528,863,869,756.0$ \\
\hline
\end{tabular}

Source: own study.

\section{CONCLUSIONS}

Based on the analysis and discussion as above, it can be concluded that optimization model of water economic value due to the land use change by using linear programming is needed 18 variables and 27 constraints as presented above. The benefit result of optimization result indicates that there is the decreasing benefit due to the land use change from 1995 until 2003 and the increasing benefit due to the land use change from 2003 until 2009. However, or the normal discharge condition: the benefit on the 1995 is $\mathrm{Rp}$. $850,923,126,361.00 ;$ on the 2003 is Rp. $868,170,664,751.00$; and on the 2009 is Rp. $727,704,108,909.00$.

\section{REFERENCES}

ANDAWAyAnTi U., RisPiningtati, ANTARIZA I.G.N. 2012. Optimum fresh water price at TITAB reservoir, Bali Province of Indonesia. Journal of Basic and Applied Scientific Research. Vol. 2(7) p. 6542-6550.

BPPT 2013. Badan Pengkajian dan Penerapan Teknologi, Indonesia [Department of Technological and Application, Indonesia].

Gakpo E., Tsephe J., Nwonwu F., Vilkoen M. 2006. Application of stochastic programming (SDP) for the optimal allocation of irrigation water under capacity sharing arrangements. Agrekon Journal. Vol. 44. Iss. 4 p. 436-451.

INWRDAM 2001. Decision support system in the field of water resources planning and management [online].
[Access 12.03.2001]. Available at: http://www.nic.gov. jo/inwrdam/dss.htm1

JuWONO P.T. 2011. Evaluation of water price due to sediment dredging at Wlingi dam, Indonesia. Journal of Basic and Applied Scientific Research. Vol. 1(7) p. 764-769.

LIMANTARA L.M. 2010. Optimization of water needs at Kepanjen dam and Sengguruh dam, East Java, Indonesia. International Journal of Academic Research. Vol. 2(5) p. 216-220.

Limantara L.M., Soetopo W. 2011. Manajemen Sumberdaya Air [Management of water resources]. Bandung. CV Lubuk Agung. ISBN 978-979-505-225-2 pp. 176.

MAYs L.W. TUNG Y.K. 1992. Hydrosystems engineering and management. New York. Mc. Graw-Hill, Inc. ISBN 0-07-041146-8 pp. 530.

PAVONi B., Voinov A., Zhavora N. 2001. Basin (watershed) approach as a methodological basis for regional decision making and management in the EX USSR [online]. [Access 12.03.2001]. Available at: http://helios.unive.it/\%7Eintas/gaboart.htm1

RISPININGTATI 2010. Model of water allocation and price for multi-functional reservoir. International Journal of Academic Research. Vol. 2(6) p. 304-307.

SATtari M.T., Kodal S., OzTURK F. 2006. Application of deterministic mathematical method in optimizing the small irrigation reservoir capacity. Journal of Akdeniz Universitesi Ziraat Fakoltesi Dergisi. Vol. 19(2) p. 261267.

SiMONOVIC S.P. 2009. Managing water resources. London. UNESCO Publ. ISBN 978-1-84407-553-9 pp. 640.

Straton A.T., Jackson S., MarinONi O., Proctor W., WOODWARD E. 2011. Exploring and evaluating scenarios for river catchment in Northern Australia using 
scenario development, multicriteria analysis and a deliberative process as a tool for water planning. Journal of Water Resources Management. Vol. 25 p. 141-164.
WARD F.A. 2009. Economic in integrated water management. Journal Environmental Model and Software. Vol. 24 p. $948-958$.

\section{Baria SATYAGRAHA, Lily Montarcih LIMANTARA, Mohammad BISRI, Ussy ANDAWAYANTI}

\section{Model optymalizacji gospodarczej wartości wody bazujący na zmianach użytkowania ziemi}

\section{STRESZCZENIE}

Zmiana użytkowania ziemi w górnej zlewni Rawa Pening coraz bardziej zdominowanej przez zabudowę mieszkalną i przemysłową powoduje wzrost odpływu powierzchniowego w porze deszczowej. Malejąca zdolność Rawa Pening do retencji wód powodziowych wpływa na okoliczne tereny uprawne. Nadmiary wody występujące w dolnej części zlewni są powiązane ze zmianami użytkowania ziemi w górnej części zlewni. Ta zależność jest ważnym powodem podjęcia optymalizacji gospodarki wodnej regionu. Zakłócenia w dostępności wody powodują zmniejszenie produkcji energii elektrycznej wytwarzanej w hydroelektrowniach, wody słodkiej i ryżu, skutkiem czego maleje optymalne wykorzystanie wody. Badania miały na celu: 1) analizę wpływu zmian użytkowania ziemi na dostępność wody; 2) analizę wpływu tych zmian na bilans wodny; 3) skonstruowanie i analizę modelu optymalizacji gospodarczej wartości wody w związku ze zmianami użytkowania ziemi. Wyniki dowodzą różnego wpływu zmian w czasie na optymalizację wartości wody.

Slowa kluczowe: model, odplyw, optymalizacja, użytkowanie ziemi 